Environmentalists and many governments are pushing for a five-year review period that would begin immediately after the Paris talks end; governments would need to return to the table with new commitments in 2020 .

Huq says that this exercise is particularly important for poor and vulnerable countries, which are pushing for a long-term goal of limiting warming to $1.5^{\circ} \mathrm{C}$. The world is likely to cross a landmark threshold, the $1{ }^{\circ} \mathrm{C}$ mark, for the first time in 2015, and Huq admits that stabilizing at $1.5^{\circ} \mathrm{C}$ would require emissions reductions so drastic as to be politically impossible at this point. But world leaders should acknowledge that even $2^{\circ} \mathrm{C}$ of warming comes with significant impacts on the world's poorest citizens, he says. "We know we are not going to get everything we want in Paris, but it's symbolic."

Samantha Smith, leader of environmental group the WWF's Global Climate and Energy Initiative in Oslo, says that the biggest debate in Paris will be over financial aid to help poor countries to reduce their emissions and cope with the impacts of climate change. In 2010, wealthy nations established a Green Climate
Fund and committed to increase climate aid to US $\$ 100$ billion annually by 2020 . Developing countries will be looking for details about that commitment and what comes next.

The good news, Smith says, is that the conversation about climate action has changed, not just within the negotiations but among faith groups, the general public and businesses, many of which will make their own voluntary emissions commitments in Paris. But she cautions that a new global treaty is just a first step. "When we walk out of there, we are still going to have a lot of work to do."

\title{
Green Climate Fund faces slew of criticism
}

\section{First tranche of aid projects prompts concern over operations of fund for developing nations.}

\section{BY SANJAY KUMAR}

$\mathrm{M}$ ajor questions are swirling around the operations of a United Nations fund that is supposed to channel billions of dollars to help developing nations adapt to climate change and slow its pace.

The Green Climate Fund (GCF) was established at UN talks in Cancún, Mexico, five years ago, and developing nations see it as one of their prime hopes for financial assistance in tackling a warming world.

Yet the fund, which is administered by a small team in Incheon, South Korea, is struggling to raise cash from rich nations. And although it approved its first aid commitments on 6 November at a meeting in Livingstone, Zambia, observers say they are concerned that the GCF has cut corners so as to announce handouts before international climate talks in Paris in December.

"We are worried about the fund's social and environmental safeguards, consultation processes, accountability mechanisms and transparency," says Brandon $\mathrm{Wu}$, a policy analyst who focuses on climate finance at the nongovernmental organization (NGO) ActionAid in Washington DC and who attended the Zambia meeting.

The Cancún agreement recommended that climate aid total US\$100 billion a year by 2020 , but the balance between private and public money, and how much of it would flow through the GCF, has not been made clear.

In the world of climate finance, the GCF is a tiny player. If funding for renewable energy and energy-efficiency programmes

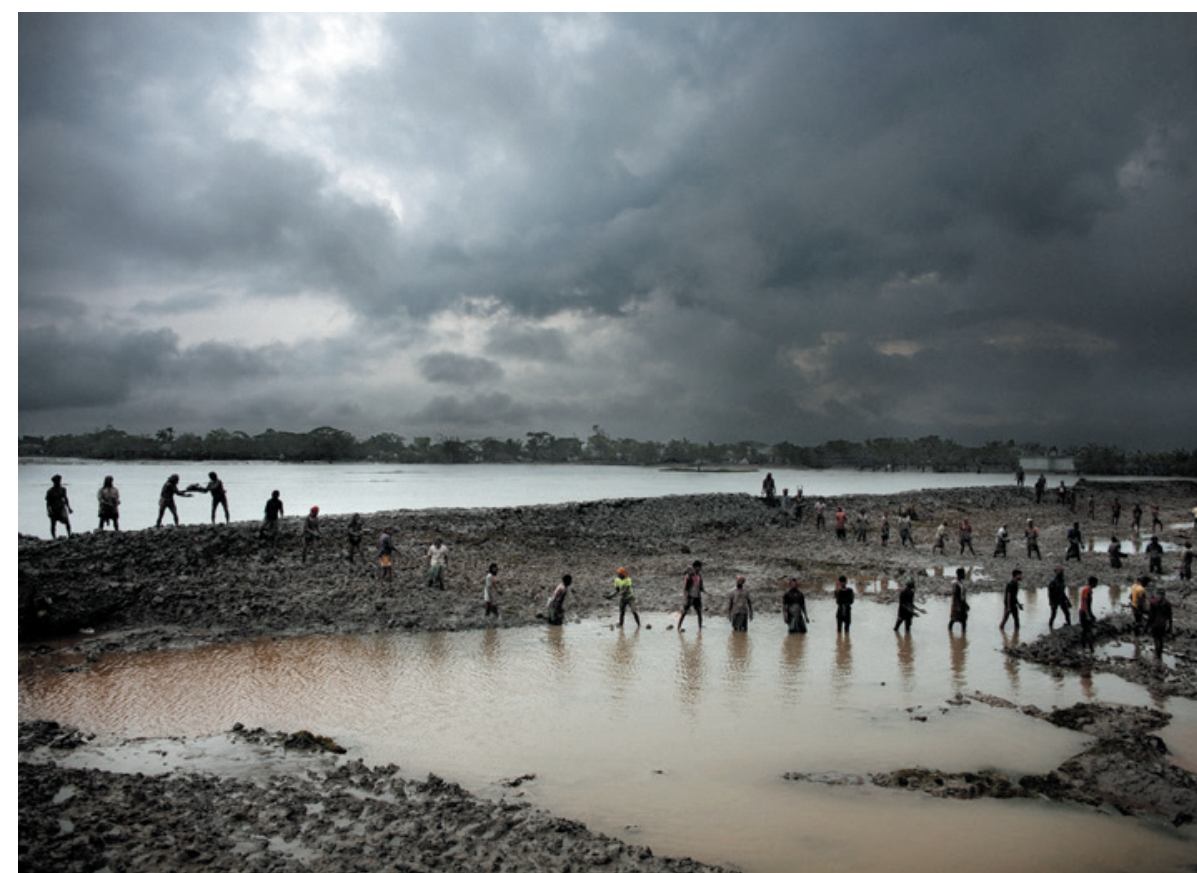

Flood barriers in Bangladesh could find support from a United Nations climate fund.

is included, hundreds of billions of dollars already flow round the globe each year, says the Climate Policy Initiative (CPI), an international think tank. Still, the GCF is the largest international public climate fund.

The fund's initial target was to collect $\$ 10$ billion before it started handing out cash, which it intends to divide equally between mitigation and adaptation projects. By October, it had received pledges of $\$ 10.2$ billion - which foreign-exchange rate variations have reduced to $\$ 9.1$ billion. But only $\$ 5.83$ billion had been formally agreed, and just $\$ 852$ million had reached the fund's pocket. The United States is the most significant missing name from the list of donor countries: last year it promised $\$ 3$ billion, but it has yet to sign an agreement to contribute money.

"At this pace we will not be able to do anything much," says Dipak Dasgupta, an economist and India's representative on the 24-person GCF board. The proposals 
> approved in Zambia - \$168 million for eight climate projects - are "small change", he says. The approvals include a wetlands resilience programme in Peru, climateresilient infrastructure in Bangladesh and a scheme of 'green bonds' to finance sustainable energy ventures in Latin America and the Caribbean, but seven of the schemes will not receive money until they meet further project-specific conditions.

Developed nations may be reluctant to transfer their money to the fund, says Timmons Roberts, who studies climate change and economic development at Brown University in Providence, Rhode Island. "Many developing countries and NGOs believe that the funding should all flow through the GCF”, he says. "However, contributor countries have always defended their ability to funnel their funds through channels they control, whether through their own bilateral agencies (like USAID) or through dedicated World Bank funds."

\section{LACK OF TRANSPARENCY}

There are also concerns about how the GCF is run, says $\mathrm{Wu}$, who attended the Zambia meeting as a permitted 'civil society observer'. Wu is worried that indigenous communities were

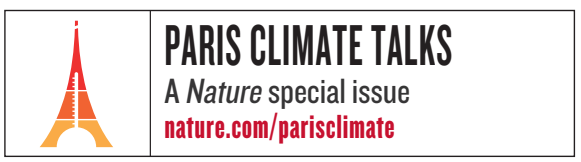

not adequately consulted before the approval of $\$ 6.2$ million for the Peruvian wetlands programme, for example. GCF documents say that a consultation was carried out, but for this and for other projects, the fund has no independent verification of its claims, says Andrea Rodríguez Osuna, who works in Mexico City for the non-profit environmental law organization AIDA and was also present in Zambia.

Nor is the GCF transparent about its processes, Rodríguez Osuna adds. "The fund has no information disclosure policy and no accountability mechanism, yet the board is approving project proposals," she says.

For the eight projects approved at the board meeting, for example, only proposal documents were publicly available (and in the case of two private-sector projects, only a summary). "These are hardly the unbiased sources of information needed to evaluate a project's merits or any potential negative impacts," Wu says. Project reviews made by the fund's board and by an independent technical advisory panel are not publicly released, and GCF officials repeatedly failed to answer questions asked by Nature for this article.

For some, another contentious issue is that the GCF is flowing its money mainly through international organizations, such as multilateral or private banks such as the World Bank and Deutsche Bank - rather than sending it directly to institutions in developing countries where the projects are taking place.

The GCF is still new and is seriously understaffed, Rodríguez Osuna adds; and observers hope that their worries are teething problems. Its executive director, Héla Cheikhrouhou, has promised "many more projects under development".

Claims have already been made that rich nations are upscaling public climate funding. But experts say that there is little clarity on whether the cash is new money, or being rerouted from elsewhere, such as from overseas development assistance funds. "Definitions of what constitutes new money haven't been agreed on," says Barbara Buchner, who leads CPI's global finance programme in Venice, Italy.

There is one thing is for certain, Buchner says - total finance for low-carbon energy projects and for adapting to and mitigating climate change is far short of estimates of the need. "We need trillions, not billions," she says.

\section{Patients demand access to compound despite lack of clinical testing.}

\section{BY HEIDI LEDFORD}

A court in the Brazilian state of São Paulo has cut off distribution of a compound that is hailed by some as a miracle cancer cure - even though it has never been formally tested in humans.

On 11 November, to the relief of many cancer researchers, a state court overturned earlier court orders that had obliged the nation's largest university to provide the compound to hundreds of people with terminal cancer. Although the reversal applies only to requests for the drug by residents of São Paulo state, administrators at the university estimate that it covers about $80 \%$ of the orders they have received for the compound.

The compound, phosphoethanolamine, has been shown to kill tumour cells only in lab dishes and in mice (A. K. Ferreira et al. Anticancer Res. 32, 95-104; 2012). Drugs that seem promising in lab and animal studies have a notoriously high failure rate in human trials. Despite this, some chemists at the University of São Paulo's campus in São Carlos have manufactured the compound for years and distributed it to people with cancer. A few of those patients

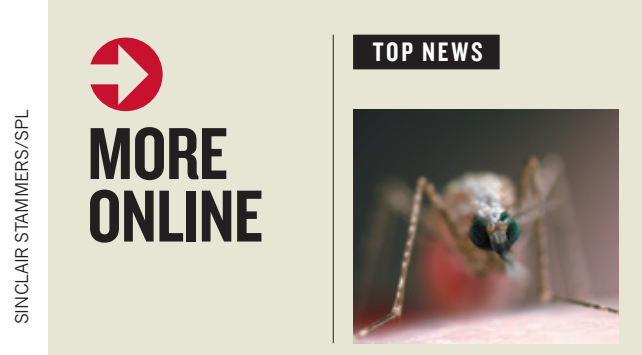

'Gene drive' mosquitoes engineered to fight malaria go.nature.com/ r53npf

\section{MORE NEWS}

- Graph-theory breakthrough tantalizes mathematicians go.nature. com $/ 8 \mathrm{mgjdx}$

- The world's biggest volcano is a magnetic mix-up go.nature.com/2mqglb - Ebola experience leaves world no less vulnerable go.nature.com/jxxvs6

\section{PARIS CLIMATE TALKS}

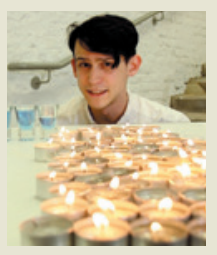

Daily news, commentary and video updates from the Paris climate talks parisclimatetalks2015. tumblr.com 